\title{
Research on the measurement of the state of the construction industry in shaanxi province
}

\author{
Fuzhou Luo ${ }^{a}$, Rui Feng \\ School of Management, Xi'an University of Architecture \& Technology, Xi'an 710055, China
}

a398429822@qq.com

Keywords: Industrial association, Input and output, the construction industry.

\begin{abstract}
As one of the important production department in national economy, the construction industry has close correlation with other sectors in the process of its own development, at the same time, plays an important role in promoting the economic development together with other sectors. In recent years, with the rapid growth of Shaanxi province construction, greatly promoted the local economic growth. In this paper, it deals with the related data of input-output table of Shaanxi in 2012, the input-output model is proposed to analyze industry association of construction industry in Shanxi province. It includes its forward related industry, after the relevant industries, as well as its own sense degree coefficient and influence coefficient in each industry rankings to calculate the Shaanxi province construction characteristic, which depends on the secondary industry and has a larger influence on other industries, however, it has an anti-poor induction degree.
\end{abstract}

\section{The analysis of the input-output of Shaanxi construction in 2012.}

The article selects the year of 2012 in Shaanxi province data input-output table of 42 departments. The Shaanxi province national economy 42 departments in every industry in 2012 of input sources and output to form, including the departments of intermediate input, use among them, the total input and end use, etc., shall be in the form of value ${ }^{[1]}$.By using the input-output model of construction industry association analysis, through the analysis of the mathematical model input and output coordination between departments, each department the balance of the relationship between production and consumption, and reveals the inner links.

\section{1 industry association state measurements}

Between the industrial connection is refers to the industry in the process of production activity of mutual influence, a particular industry Changes in the drives changes in other industries. Industry associations have forward related industry and back to the two kinds of related industries.

Forward connection. Forward correlation refers to the $\mathrm{x}$ industry in the process of the change of production cost will be caused to the related departments before the change in some ways, of its role. Usually expressed in direct distribution coefficient.

Direct distribution coefficient formula is expressed as:

$$
h_{i j}=\frac{Z_{i j}}{X_{i}} \quad(i, j=1,2, \ldots, n)
$$

Among them, hij express $\mathrm{i}$ department in the case of production per unit product, direct distribution coefficient of $\mathrm{j}$ department products; $\mathrm{Zij}$ express $\mathrm{i}$ division in the case of production per unit product, the product by the department of $\mathrm{j}$ direct allocation amount; Xi said the department's output i

Backward connection. To relevance refers to the $\mathrm{x}$ industry in the process of the change of the consumption in cause subsequent to the related departments in some aspects of demand change, usually use the direct consumption coefficient and complete consumption coefficients to be expressed.

Using the direct consumption coefficient formula is expressed as:

$$
\mathrm{a}_{\mathrm{ij}}=\frac{\mathrm{X}_{\mathrm{ij}}}{\mathrm{x}_{\mathrm{j}}}(\mathrm{i}, \mathrm{j}=1,2, \ldots, \mathrm{n})
$$


Among them, the direct consumption coefficients aij refers to in the process of production and operation, the first $\mathrm{j}$ products division direct consumption by unit output of the products division I the value of the goods or services; Which is the first $\mathrm{j}$ department's total $\mathrm{xj}$ remove direct consumption in the production and operation of the department of the division I the number of goods or services xij.

Complete consumption coefficients with formula is expressed as:

$B=(I-A)^{-1}-I$

B express completely consumption coefficient matrix, completely consumed by direct consumption and indirect cost; A for direct consumption coefficient matrix. B show that the greater the construction of other production departments fully consumption was greater, as construction pull influence on the other production departments.

\section{2 the measurement method of industry position}

Industry status refers to a particular industry sector's role in the national economy and the role, can be used to represent the influence coefficient and sense degree coefficient. Influence coefficient is used to represent a particular industry sector in the national economy influence on other industries in the size, show that the proposed changes on the degree of influence and spread to other departments. Its value, the greater its pull function to other sectors. Fj influence coefficient calculation formula is:

$$
F_{\mathrm{j}}=\sum_{\mathrm{i}=1}^{\mathrm{n}} \mathrm{p}_{\mathrm{ij}} /\left(\frac{1}{\mathrm{n}} \sum_{\mathrm{j}=1}^{\mathrm{n}} \sum_{\mathrm{i}=1}^{\mathrm{n}} \mathrm{p}_{\mathrm{ij}}\right)
$$

Among them, $\sum_{\mathrm{i}=1}^{\mathrm{n}} \mathrm{p}_{\mathrm{ij}}$ Refers to the leontief coefficient and the matrix $\mathrm{j}$ industry is located in the column. $\mathrm{Fj}>1$, the industry sector pull function on the social than the social average level; $\mathrm{Fj}=1$, the industry sector pull function on the society to achieve the social average level; $\mathrm{Fj}<1$, the industry sector pull function on the society is lower than the social average level ${ }^{[2]}$.

Induction coefficient expression of relative to all industries, an industry to other industry the driving force of size. Induction degree coefficient is larger, the department of the role of other departments. Ei induction degree coefficient calculation formula is:

$$
E i=\sum_{\mathrm{j}=1}^{\mathrm{n}} \mathrm{p}_{\mathrm{ij}} /\left(\frac{1}{\mathrm{n}} \sum_{\mathrm{i}=1}^{\mathrm{n}} \sum_{\mathrm{j}=1}^{\mathrm{n}} \mathrm{p}_{\mathrm{ij}}\right)
$$

Among them, $\sum_{\mathrm{j}=1}^{\mathrm{n}} \mathrm{p}_{\mathrm{ij}}$ Refers to the leontief matrix I coefficient and the industry in line $\sum_{\mathrm{i}=1}^{\mathrm{n}} \sum_{\mathrm{j}=1}^{\mathrm{n}} \mathrm{p}_{\mathrm{ij}}$ Refers to the leontief the sum of all the industries in the matrix coefficient. Ei $>1$, the industry sector of social role is higher than the social average level; If Ei $=1$, the industry sector of social role to achieve the social average level; If $\mathrm{Ei}<1$, the industry department of social role is lower than the social average level.

\section{Correlation of construction industry in shaanxi province}

Industry association refers to a certain industrial sectors of national economy in production, changes in technology and its supply and demand relation of other industrial sectors, according to the relationship between demand and supply is divided into forward and backward. They have contact with other parts of the supply is referred to as forward associated industries, and its existence needs contact to related industry after industry department called.

\subsection{The forward connection industry of construction in shaanxi province.}

Input-output table in the year of 2012 in shaanxi province as the calculation basis, use the formula (1) indicates that the main sectors related to the construction of direct distribution coefficient, sorted shown in the following table. 
Table 1 the main direct relevance industry to the construction industry in shaanxi province

\begin{tabular}{|c|c|c|}
\hline department & $\begin{array}{c}\text { Direct distribution } \\
\text { coefficient }\end{array}$ & ranking \\
\hline Public management, social security and social organization & 0.00431 & 1 \\
\hline education & 0.00245 & 2 \\
\hline The financial sector & 0.00224 & 3 \\
\hline Transportation, warehousing and postal service & 0.00189 & 4 \\
\hline Coal selecting products industry & 0.00128 & 5 \\
\hline Nonmetal mineral products & 0.00105 & 6 \\
\hline Metal smelting and rolling processed products industry & 0.00094 & 7 \\
\hline Wholesale and retail & 0.00073 & 8 \\
\hline Health and social work & 0.00066 & 9 \\
\hline Culture, sports and entertainment & 0.00055 & 10 \\
\hline
\end{tabular}

The direct distribution coefficient, the greater the instructions for the more significant role in promoting the industry sector. In the industrial sector as shown in table 1, it is easy to find, the third industry and construction industry have very obvious forward directly related ${ }^{[3]}$. This also with our daily know, education, finance, entertainment industries such as need the supply of construction, the construction of direct demand is big, construction department directly to other industries to provide its production, life need place and the environment. The construction of the third industry is also very obvious and prominent role.

\subsection{The backward correlation of construction in shaanxi province}

Backward association including direct relevance to the industry and after to completely correlation industry, respectively using the direct consumption coefficient and complete consumption coefficients to be said.

The direct backward correlation of the construction in shaanxi province. After the direct correlation with the direct consumption coefficient. Input-output table in the year of 2012 in shaanxi province as the calculation basis, use the formula (2) indicates that the main sectors related to the construction of the direct consumption coefficient, sorted shown in the following table.

Table 2 in shaanxi province construction before the main direct relevance to the industry and the correlation

\begin{tabular}{|c|c|c|}
\hline department & $\begin{array}{c}\text { Direct consumption } \\
\text { coefficient }\end{array}$ & ranking \\
\hline Metal smelting and rolling processed products industry & 0.1773 & 1 \\
\hline Non-metallic mineral products & 0.1712 & 2 \\
\hline Leasing and business services & 0.0654 & 4 \\
\hline $\begin{array}{c}\text { And other non-metallic mineral ore selecting products } \\
\text { industry }\end{array}$ & 0.0501 & 5 \\
\hline Fabricated metal products & 0.0312 & 6 \\
\hline Transportation, warehousing and postal service & 0.0306 & 7 \\
\hline Electrical machinery and equipment industry & 0.0261 & 8 \\
\hline Processed wood and furniture industry & 0.0214 & 9 \\
\hline Chemical products industry & 0.0211 & 10 \\
\hline Oil and fuel products industry & 0.0184 & 3 \\
\hline
\end{tabular}

After the state to the direct consumption coefficient, the greater the demand for this industry to other industry departments, the more significant role. In the industrial sector as shown in table 2 , it is easy to find, construction main need the supply of the second industry department, the second industry, the main consumption such as construction in developing need metals, nonmetal, wood and furniture industry of the second industry support ${ }^{[4]}$. This is also consistent with our daily knowledge 
that the development of construction industry will pull the metals and non-metallic industry, furniture industry prosperity of the second industry.

The completely backward correlation of the construction in shaanxi province. In 2012 input-output table of shaanxi province as the calculation basis, use the formula (3) indicates that the main sectors related to the construction of consumption coefficients, completely sorted shown in the following table.

Table 3 shaanxi construction backward relevant industries

\begin{tabular}{|c|c|c|}
\hline department & $\begin{array}{c}\text { The direct consumption } \\
\text { coefficients }\end{array}$ & ranking \\
\hline Metal smelting and rolling processed products industry & 0.1773 & 1 \\
\hline Non-metallic mineral products & 0.1712 & 2 \\
\hline Electricity, heat production and supply industry & 0.0654 & 3 \\
\hline Chemical products industry & 0.0501 & 4 \\
\hline Leasing and business services & 0.0312 & 6 \\
\hline Metallic ore selecting products industry & 0.0306 & 7 \\
\hline And other non-metallic mineral ore selecting products \\
industry & 0.0261 & 8 \\
\hline Coal selecting products industry & 0.0214 & 9 \\
\hline Transportation, warehousing and postal service industry & 0.0211 & 10 \\
\hline Metal products, machinery and equipment repair services ind \\
ustry
\end{tabular}

Table 4 the influence coefficient of the top ten industries in shaanxi province, China

\begin{tabular}{|c|c|c|}
\hline Department & Influence coefficient & Ranking \\
\hline Metal products, machinery and equipment repair services & 1.3386 & 1 \\
\hline Electrical machinery and equipment industry & 1.3213 & 2 \\
\hline Transportation equipment industry & 1.2743 & 3 \\
\hline Metal smelting and rolling processed products industry & 1.2665 & 4 \\
\hline General equipment industry & 1.2382 & 5 \\
\hline Metal Products industry & 1.2304 & 6 \\
\hline construction industry & 1.2179 & 8 \\
\hline Special equipment industry & 1.2132 & 9 \\
\hline Communication equipment, computers and other electronic eq & 1.1927 & 10 \\
\hline Electricity, heat production and supply industry & 1.1912 & \\
\hline
\end{tabular}

After to complete consuming coefficient table and to direct consumption coefficient table industry is roughly same, such as metal, nonmetal industry, chemical industry, etc., the second industry sector. Indicates that the development of construction industry will lead to the development of the second industry. The ripple effect of construction in shaanxi province industry is to point to in the industry of national economy system, when a sector changes, this change along the different ways of industrial connection, cause is directly related with the change of the industrial sector, and through the department's change and its process is directly related to changes in other sectors. Caused by 
enterprise spread between industry can be roughly divided into two kinds: the influence of the influence of the industry and the degree of induction of industry. One industry influence the level of other industries is called the industry's influence, the degree of the industry is affected by other industries as the industry's induction.

\subsection{The influence coefficient of construction in shaanxi province}

Put Input-output table the year of 2012 in Shanxi Province as the calculation basis, calculated with formula (4).

Construction influence coefficient is greater than 1, and instructions on other sectors of national economy of shaanxi province construction got greater than the social average level, the construction industry in the input link impact on other industry scale, also suggests that the demand of construction market is very big.

\subsection{The induction degree influence coefficient of construction in shaanxi province}

Put the year of 2012 input-output table of shaanxi province as the calculation basis, use the for mula (5) in 42 sectors that induction degree coefficient, sorted shown in the following table. The ind uction degree coefficient of construction in Shanxi Province, ranked 34th in 42sectors 。

Table 5 induction force coefficient in Shanxi Province industry rankings

\begin{tabular}{|c|c|c|}
\hline department & response coefficient & Ranking \\
\hline Metal smelting and rolling processed products industry & 3.4141 & 1 \\
\hline Electricity, heat production and supply industry & 2.7093 & 2 \\
\hline Transportation, warehousing and postal service & 2.5512 & 3 \\
\hline Chemical products industry & 2.4712 & 4 \\
\hline Metal products, machinery and equipment repair services & 1.7264 & 5 \\
\hline Coal selecting products industry & 1.599 & 6 \\
\hline Financial sector industry & 1.5201 & 7 \\
\hline Renting and Commercial Services industry & 1.4587 & 8 \\
\hline $\begin{array}{c}\text { Communication equipment, computers and other electronic eq } \\
\text { uipment industry }\end{array}$ & 1.4191 & 9 \\
\hline Electrical machinery and equipment industry & 1.3016 & 10 \\
\hline construction industry & 0.4891 & 34 \\
\hline
\end{tabular}

42 sectors in the construction industry ranked 34 induction degree coefficient, sense degree coefficient is less than 1, lags far behind other industries, showed the construction compared to other industries to lower the driving force of the national economy. Should pay attention to the construction industry sector development, active development of construction industry.

\section{Summary}

As we can be seen through the above analysis, and construction is closely related to the former mainly concentrated in the tertiary industry to industry, construction industry to promote the third industry, to promote the development of the third industry very well. At the same time associated with the close to the industry mainly focused on the second industry, namely, its dependence on the second industry is larger, the second industry mainly relies on consumption to promote its development. Second, the construction influence coefficient is larger, the leading role is more significant. Construction induction degree coefficient is low, that other industries on the development of driving force is relatively weak, should be paid to focus on, make it a better contribute to economic development. Construction industry as the pillar industry of shaanxi province, analysis to the industry association, to make economic development strategy and industry policy is of great significance. 


\section{Acknowledgements}

This study is supported of Minstry of Housing and Urban-Rural Science and Technology Project named Development of Real Estate Markrt in West Resources Cities: Difficulties, Reasons and Countermeasures--Ordos, Yulin Case (2015R4005).

\section{References}

[1]Guiwen Liu, Yarong Zhang.Construction industry association state analysis - but so do dungans and jiangsu for example [J]. Journal of engineering management, 2013.

[2]Dongshui Su. Industry economics [M]. Beijing: higher education press, 2005.

[3]Xia Li .Chinese construction industry based on the theory of the industrial connection analysis [D]. Shandong Construction University, 2012.

[4]Yanhui Li. Based on input-output technology construction in jiangxi province empirical analysis [J]. Industrial market. 